кількості виконаних наукових проєктів та дотримання вимог законодавства і при цьому не завжди розглядає їх як джерело фінансування і/або створення репутації. Виявлено відсутність єдиного бачення щодо управління науковою роботою в закладах вищої освіти; виявлено, що управління чією складовою діяльності закладів має тенденцію бути консервативним. Ерективність досліджень управляється й контролюється за допомогою нормативних документів і розроблених критеріїв.

Ключові слова: вища освіта, теоретичні концепції управління, підходи до управління, дослідницька складова.

\title{
PEЗЮME
}

Шихненко Екатерина. Теоретические концепции управления высшим образованием: исследовательская составляющая.

В работе определены характеристики исследовательской составляющей в концепциях менеджента, которые используются для управления образовательными учреждениями в Украине. Выяснено, как в различных типах высиих учебных заведений указанные характеристики соотносятся с такими подходами к управлению, как репутационный, ориентированный на процесс и ориентированный на стандарт. Раскрывается, как особенности каждой концепции были представлены в институциональных учредительных документах, таких как Устав университета, и в какой степени стейкходлеры учреждений были осведомлены о том, как осуществляется управление научной работой в их учреждениях. Исследование было эксплоративным и использовало качественные методы для сбора данных, полученных на основе мнений участников. Оно включало два этапа: анализ литературы $и$ опрос. Обзор литературы и анализ институциональных учредительных документов выявили характеристики исследовательской составляющей в концепциях управления. Также было установлено, что критериями управления эфрфективностью исследований являются репутационный, ориентированный на процесс (квалиметрический) и ориентированный на стандарт (релятивистский).

Ключевые слова: высшее образование, теоретические концепции управления, подходы к управлению, исследовательская составляющая.

удк 342. 9

Марина Ячменик

Сумський державний педагогічний університет імені А.С. Макаренка ORCID ID 0000-0003-3547-046X

DOI 10.24139/2312-5993/2020.08/342-351

\section{АКАДЕМІЧНА ДОБРОЧЕСНІСТЬ ЯК ЕЛЕМЕНТ ЗАБЕЗПЕЧЕННЯ ЯКОСТІ ОСВІТИ У ВИЩІЙ ШКОЛІ: ДОСВІД СУМСЬКОГО ДЕРЖАВНОГО ПЕДАГОГІЧНОГО УНІВЕРСИТЕТУ IMЕНІ А. С. МАКАРЕНКА}

у науковій розвідці здійснено спробу дослідити забезпечення принципів академічної доброчесності в освітньому просторі закладів вищої освіти як основи якості освіти.

На прикладі результатів опитування здобувачів вищої освіти та науковопедагогічних працівників, проведеного в Сумському державному університеті імені 
А.С. Макаренка про дотримання принципів академічної доброчесності під час викладання освітньо-профресійних програм, надано авторський коментар щодо отриманих відповідей та запропоновано інструментарій упровадження принципів академічної доброчесності у вищій школі: проведення відкритих лекцій, тренінгів, вебінарів, тижнів академічної доброчесності, роз'яснення мети академічної сумлінності й відповідальності, причин і видів порушень, способів боротьби з ними в науковій та профресійній взаємодії стейкхолдерів.

Ключові слова: академічна доброчесність, якість освіти, вища школа, система забезпечення якості вищої освіти, система забезпечення академічної доброчесності; навчальна та науково-дослідна діяльність здобувачів вищої освіти.

Постановка проблеми. У Національній доктрині розвитку освіти України у XXI столітті якість освіти визначено як основний пріоритет державної науково-освітньої політики й передумову національної безпеки держави. Якість освітнього процесу є невід'ємною складовою якості освіти та поєднує якісні й кількісні показники освітнього процесу, професійної компетентності викладачів, організаційно-управлінської компетентності: забезпечує ефективність і результат функціонування освітнього процесу та обумовлює розвиток нових підходів до викладання і навчання на засадах корпоративної етики, продуктивної, толерантно-ціннісної комунікації між усіма представниками стейкхолдерів, принципах академічної доброчесності. Згідно з п. 8 ч. 2 ст. 16 Закону України «Про вищу освіту», внутрішня система якості вищої освіти має забезпечувати «дотримання академічної доброчесності працівниками закладів вищої освіти та здобувачами вищої освіти». Відповідно до Рекомендацій з академічної доброчесності для закладів вищої освіти Міністерства освіти і науки України (Рекомендації, 2018), розроблених на основі вивчення успішного міжнародного досвіду підтримки принципів академічної доброчесності в межах Проєкту сприяння академічної доброчесності в Україні - SAIUP за підтримки Посольства США, система забезпечення академічної доброчесності має містити процедури та заходи, відповідну нормативно-правову базу (кодекси, положення, правила, пам'ятки тощо), будуватися на набутті студентами компетентностей із академічної доброчесності, навичок якісного академічного письма, роботі $з$ викладацьким колективом, створенні Етичного кодексу та етичної комісії, санкціях за порушення академічної доброчесності, унормуванні вимог та особливостей перевірки на академічний плагіат письмових робіт.

Аналіз актуальних досліджень. Проблемі підвищення якості освітнього процесу присвячені дослідження таких учених, як В. Бондар, Л. Даниленко, Т. Лукіна, Н. Островерхова, В. Панасюк, М. Поташник та ін. Сутність поняття академічної доброчесності розглянуто в роботах МДж. Бейлі, Р. Барбато, А. Ковальова, Г.Ульянової, О.Харитонової та ін. У наукових працях 
вітчизняних учених: А. Артюхова, Т. Фінікова, В. Лугового, О. Слюсаренко, Ж. Таланової, В. Астахової, В. Сацика, О. Семеног - академічна доброчесність постає як фундамент розвитку університету та формування сучасного конкурентоспроможного фахівця. Однак, мало вивченим залишається питання академічної доброчесності як елементу забезпечення якості вищої освіти, що й зумовило проблематику нашого дослідження.

Мета статті - дослідити систему формування академічної доброчесності в освітньому просторі закладів вищої освіти як елементу забезпечення якості освіти, зокрема на прикладі Сумського державного педагогічного університету імені А.С. Макаренка.

Для досягнення зазначеної мети використовувалися такі методи дослідження: узагальнення наукових джерел, аналіз використаної літератури, теоретичне моделювання, педагогічний експеримент тощо.

Виклад основного матеріали, У «Проєкті Державного стандарту вищої освіти «Вимоги до підготовки фахівців освітньо-кваліфікаційного рівня бакалавр» поняття якість освіти потрактовано як виконання державних вимог до кадрового, навчально-методичного, матеріально-технічного забезпечення навчального процесу, до організації практик, професійної підготовленості бакалавра, підсумкової державної атестації для якісної підготовки конкурентноспроможних фахівців (Яременко, 2001). У розвідках науковців якість освіти постає як багатогранна, багатоаспектна та багатопараметрична категорія в таких вимірах: суспільний ідеал освіченості людини; результат їі навчальної діяльності; процес організації навчання і виховання; критерій функціонування освітньої системи (Тализін, 2006); визначається сукупністю показників, що характеризують різні аспекти навчальної діяльності освітньої установи: зміст освіти, форми й методи навчання, матеріально-технічну базу, кадровий склад і тому подібне, які забезпечують розвиток компетентностей учнів (Шишов, 2000). Більшість авторів якість освіти інтерпретують як єдність якості процесу і якості результату (Панасюк, 2007) через певний рівень розвитку особистості - конкурентноспроможний затребуваний випускник на ринку праці: певний рівень знань і вмінь, розумового, фізичного і морального розвитку, якого досягли випускники освітнього закладу відповідно до запланованих цілей (Полянский, 1999) відповідно до професійної підготовки суб'єктів викладання, їхніх особистісніх якостей (порядність, відповідальність, принциповість, толерантність тощо) (Коротков, 2004) на засадах академічної доброчесності.

у межах нашого наукового дослідження вважаємо за потрібне розглянути поняття академічної доброчесності. Поняття «чесний» у 
тлумачному словнику української мови А. Івченка потрактовано як високі моральні якості (Івченко, 2002). у Фундаментальних цінностях академічної доброчесності Міжнародного центру академічної доброчесності при Ротлендському інституті етики (США) визначено феномен академічної доброчесності як відданість академічної спільноти цінностям: Чесності; Довірі; Справедливості; Повазі; Відповідальності; Мужності (Fishman, 2012).

Наукова думка М. Бадіци розрізняє поняття доброчесності як моральної якості особистості та поняття доброчесний як людини, яка діє відповідно до етичних норм і правил та потрактувує академічну доброчесність як дотримання особистістю етичних норм на засадах культуровідповідності в процесі викладання та навчання (Бадіца, 2019). Академічна доброчесність для закладу вищої освіти - це соціальний капітал сучасного університету, який проявляється у формуванні нової академічної культури на принципах академічної свободи, суспільної відповідальності, пошани до людської гідності, адже головний капітал майбутнього - це креативні люди з високим інтелектом, винахідливістю, мотивацією і творчими здібностями (Пшенична, 2019).

Досліджуючи систему забезпечення академічної доброчесності як елементу якості вищої освіти в умовах Сумського державного педагогічного університету імені А. С. Макаренка, зупинимося на опитуванні здобувачів вищої освіти щодо дотримання академічної доброчесності під час реалізації освітньо-професійної програми. Аналіз анкет дав змогу встановити, що 84,3 \% респондентів знайомі з поняттям академічна доброчесність. 97,6 \% відоме поняття плагіат та можливі ризики, пов'язані з ним. Серед запропонованих проявів академічної недоброчесності (питання 4): 169 респондентів віднесли академічний плагіат; 132 - хабарництво; 119 - необ'єктивне оцінювання; 102 особи вважають академічною недоброчесностю фальсифікацію; 54 самоплагіат; 52 - фабрикацію; 70 - усе з перерахованого вище. Респонденти (82,3 \%) ознайомлені з тим фактом, що в університеті використовують програмні продукти для виявлення плагіату в студентських роботах. На думку респондентів, до такої перевірки слід залучати: конкурсні роботи $(69,9 \% 3$ опитаних); наукові статті (60,2 \% з опитаних); підручники (44,2 \%); посібники (39 \%); монографії (43,9%); завдання індивідуальних робіт (26,5 \%); тези доповідей (14,9%). 5 здобувачів вищої освіти вважають, що перевіряти на плагіат слід тільки курсові та кваліфікаційні роботи, а 46 респондентів вважають, що перевіряти слід все з переліченого. При цьому 92,4\% респондентів знають про заходи, які вживаються під час виявлення академічного плагіату. Зокрема, вони вказали на такі: виконання роботи не 
зараховується $(65,5 \%)$; здійснюється вибіркова повторна перевірка на плагіат $(45,8 \%) ;$ проводяться роз'яснювальні бесіди $(43,4 \%) ;$ робота студента не допускається до захисту $(38,2 \%) ;$ доопрацювання роботи $(36,9 \%) ;$ негативний вплив на підсумкову оцінку (38,6 \%); відбувається зміна теми роботи (14,9\%); відрахування студента (11,2\%).

Під час навчання в університеті трохи більше половини опитаних (55,8 \%) вдавалися до академічної недоброчесності, зокрема: підказки одногрупників $(39,8 \%)$, списування $(30,9 \%)$, використання шпаргалок $(29,7 \%)$. Перевірку роботи на запозичення здобувачі вищої освіти в університеті роблять самостійно (21,3\%). 12,9\% ніколи не проводили перевірку власних робіт на плагіат. $6 \%$ респондентів зазначають, що копіюють текст із інтернету без змін та відповідних посилань. У своїй більшості респонденти (57,8 \%) відмітили, що знайомі з нормативними документами, що діють в університеті щодо академічної доброчесності.

Серед опитаних здобувачів вищої освіти 57 \% зазначили, що в університеті (на факультеті, в інституті) проводяться ознайомлювальні заходи щодо процедури дотримання академічної доброчесності (наукові семінари, тренінги тощо). Тому однією з головних пропозицій щодо підвищення рівня академічної доброчесності студенти вважають збільшення роз'яснювальної роботи (34,8 \%).

3 урахуванням даних моніторингу онлайн-опитування здобувачів вищої освіти з академічної доброчесності спільним засіданням Комісії з етики та академічної доброчесності, Комісії з якості, Центру забезпечення якості вищої освіти, представників студентського самоврядування було розглянуто інструменти утвердження системи забезпечення академічної доброчесності в Сумському державному педагогічному університеті імені А. С. Макаренка, нормативно-правовою базою для яких стали: Кодекс академічної доброчесності (наказ №420 від 30 вересня 2019 р.) (https://sspu.edu.ua/images/2019/manual/kodeks akademichnoyi dobroches nosti 6c82c.pdf), Наказ про створення Комісії з питань етики та академічної доброчесності (наказ No420 від 30.09.2019) (https://sspu.edu.ua/images/2019/manual/polozhennya_pro_komisiyu_z_pita n_etiki_ta_akadem_dobrochesnosti_f788c.pdf), яка $\epsilon$ дорадчим органом університету та наділяється правом розглядати заяви щодо порушення академічної доброчесності, Положення про систему забезпечення академічної доброчесності в освітньо-науковій діяльності (https://sspu.edu.ua/images/2020/doc/polozhennya pro sistemu zabezpeche nnya ad 2866f.pdf), Положення про центр забезпечення якості вищої 
СумДПУ

імені

А. C. Макаренка»

(https://sspu.edu.ua/images/2020/doc/polozhennya_pro_komisiyu_iz_zabezp echennya_yakosti_vischoyi_osviti_5d370.p df), що містять чіткі правила діяльності 3ВО, шляхи популяризації, пропагування академічної культури та доброчесності в освітньому та науковому процесах Університету.

На основі існуючих європейських і вітчизняних практик, нормативних документів, матеріалів та кейсів Національного агентства із забезпечення якості вищої освіти принципи впровадження та пропагування норм академічної доброчесності, утверджені документи знайшли відображення у проведених заходах на рівні закладу вищої освіти, навчально-наукових інститутів, факультетів та освітньо-професійних програм, що відображено на web-сторінці сайту Університету (розділ «Якість освіти»), мета якої інформувати здобувачів вищої освіти щодо здійснення заходів із питань якості освіти та академічної доброчесності в СумДПУ імені А. С. Макаренка (https://sspu.edu.ua/akademichna-dobrochesnist) та створення інформаційної бази на сайті університету (онлайн-курси освітніх платформ ED-ERA, Prometeus) для самоосвіти всіх стейкхолдерів із основ академічної відповідальності; систематичному Інформаційному віснику з питань якості вищої освіти та принципів упровадження академічної доброчесності в Сумдпу імені А. С. Макаренка (https://sspu.edu.ua/informatsiinyi-visnyk); роботі структурних підрозділів - Центру забезпечення якості вищої освіти, інститутів, деканатів, уповноважених Комісій з академічної доброчесності та якості освіти, наукової лабораторії «Академічна культура молодих дослідників», які забезпечують популяризацію принципів академічної доброчесності серед академічної макаренківської спільноти.

Інструментами поширення принципів академічної доброчесності стали лекції від стейкхолдерів - усеуніверситетська зустріч зі здобувачами вищої освіти та науково-педагогічними працівниками в листопаді 2019 року з координатором Проєкту сприяння академічній доброчесності в Україні Т. Тимочко, усеуніверситетська лекція-діалог стейкхолдерів із академічної культури і академічної доброчесності (запрошений стейкхолдер А.П.Рябуха - начальник управління державної служби якості освіти в Сумській області) у СумДпу) (https://sspu.edu.ua/news/lektsiya-dialog-izakademichnoji-kulturi-i- akademichnoji-dobrochesnosti-profesora-semenog-o-mu-sumdpu); онлайн-тренінги в межах реалізації всеукраїнських та міжнародних проєктів із інфомедійної грамотності та академічної доброчесності: викладачі кафедр української мови і літератури, всесвітньої історії та методики викладання, мистецтва реалізовують ґрантовий проєкт 
«Вивчай і розрізняй: інфомедійна грамотність» від IREX (одним із компонентів якого $\epsilon$ подвійна імплементація медіаграмотності й академічної доброчесності) та $€$ сертифікованими учасниками тренінгів із академічної доброчесності під час Зимової школи IREX, АУП (тренери - Є. Ніколаєв, В. Бахрушин, Я. Чапайло та ін.), інфомедійної грамотності (О. Тараненко, Л. Квасюк, В. Іванов, Т. Іванова). На основі знань, отриманих під час тренінгів та набутих компетентностей за рахунок опрацювання курсу з «Академічної доброчесності» на платформі EdEra, протягом квітня-травня М. Ячменик керівник Центру зяВО, О. Семеног - керівник Лабораторії академкультури, Л. Пшенична - перший проректор, В. Козлова - координаторка Комісії з етики та академічної доброчесності на факультеті іноземної та слов'янської філології, А.Вертель - координатор Комісії 3 етики та академічної доброчесності в навчально-науковому інституті педагогіки і психології та ін. провели серію онлайн-зустрічей для макаренківської спільноти - вебінари «Академічна доброчесність - тренд сучасної освіти» (https://sspu.edu.ua/akademichna-dobrochesnist\#sppb-modal-1589916188900); «Академічна доброчесність під час дистанційного навчання» (https://sspu.edu.ua/akademichna-dobrochesnist\#sppb-modal-1587227635974), що в умовах дистанційного навчання сприяло швидкій адаптації в підготовці та проведенні лекційних, практичних занять. Інформаційно-технологічна діяльність фахівців наукової бібліотеки та репозитарію університету (https://sspu.edu.ua/media/attachments/2020/04/22/strikeplagiarism.pdf) у співпраці з представниками StrikePlagiarism (онлайн-зустріч у квітні 20192020 н.р.). Започаткована щорічна Декада академічної доброчесності (https://sspu.edu.ua/akademichna-dobrochesnist); підписання Декларації 3 академічної доброчесності науково-педагогічних працівників та здобувачів вищої освіти; обов'язкова перевірка наукових та кваліфікаційних робіт на наявність ознак академічного плагіату.

Протягом трьох років активну роботу серед студентського наукового товариства з питань академічної культури популяризує Наукова Лабораторія «Академічна культура молодих дослідників» (керівник - професор Семеног O.M.) (https:// www.facebook.com/groups/ 1204591119886308/ ?ref=bookmarks). Результатом роботи Науково-дослідної лабораторії $€$ щорічна Міжнародна науково-практична конференція «Академічна культура дослідника в освітньому просторі: європейський та національний досвід» (https://sspu.edu.ua/news/akadem-chna-kul-tura-dosl-dnika-v-osv-tn-omuprostor-evropejs-kij-ta-nats-onal-nij-dosv-d, збірник наукових праць науковопедагогічних працівників та здобувачів вищої освіти з питань академічної 
культури, академічної доброчесності, інфомедійної грамотності, корпоративної етики Сумського державного педагогічного університету імені А. С. Макаренка. Зокрема, під час усеукраїнської науково-практичної конференції студентів, аспірантів та молодих учених із міжнародною участю «Академічна культура дослідника в освітньому просторі» у 2017 році обговорювалися питання щодо формування академічної культури педагогівдослідників, культури навчання, цінностей, традицій, норм, правил проведення наукового дослідження, наукової мовної культури, культури духовності і моралі, спілкування наукових наставників та учнів, соціальної, моральної відповідальності; пронизування освітніх програм підготовки культурою толерантності й педагогічного оптимізму, що формується в культурноосвітньому просторі закладу вищої освіти (Семеног, 2016).

Інструментами контролю $є$ здійснення анкетування здобувачів вищої освіти та науково-педагогічних працівників (https://sspu.edu.ua/media/attachments/2020/09/04/zvitad.pdf; з затвердження анкет шляхом обговорення на спільному засіданні Комісії 3 етики та академічної доброчесності (представники науково-педагогічних працівників, студентського самоврядування та здобувачів вищої освіти, Центр забезпечення якості вищої освіти) (протокол № 3 від 27 квітня 2020 р.).

Висновки та перспективи подальших наукових розвідок. Академічна доброчесність $€$ одним із головних елементів забезпечення якості освіти у вищій школі, підґрунтям для ефективної співпраці здобувачів вищої освіти та викладачів на основі єдиної системи моральних цінностей, що сприяє забезпеченню й посиленню якості підготовки конкурентноспроможних фахівців та комунікативного діалогу, довірі між стейкхолдерами, побудованій на чесності та відповідальності, що і стане предметом дослідження подальших наукових розвідок.

\section{ЛІТЕРАТУРА}

Fishman, T. (2012). The Fundamental Values of Academic integrity (2nd edition). International Centre for Academic integrity Clemson University Available at: http:// www. Academicintegrity.org/icai/assets/AUD_ integrity_Quotes. Pdf.

Бадіца, М. (2019). Академічна доброчесність як стратегічна мета вищої освіти. Академічна доброчесність: виклики сучасності. Збірник наукових есе учасників дистанційного етапу наукового стажування для освітян (Республіка Польща, Варшава, 24.06 - 06.07.2019). Варшава (Baditsa, М. (2019). Academic integrity as a strategic aim of higher education. Academic integrity: the challenges of today. The book with scientific essays of participants of the distance stage of scientific internship for educators (Republic of Poland, Warsaw, 24.06 - 06.07.2019). Warsaw).

Івченко, А. (2002). Тлумачний словник української мови. Харків: Фоліо (Ivchenko, А. (2002). Explanatory dictionary of the Ukrainian language. Kharkiv: Folio). 
Коротков, Е. (2004). Качество образования: формирование и оценка, управление. М.: гуy (Korotkov, E. (2004). The quality of education: formation and assessment, management. Moscow: SUU).

Панасюк, В. (2007). Використання досвіду управління якості освіти. Підручник для директора, 8, 42-51 (Panasiuk, V. (2007). Using the experience of management of the quality of education. A textbook for the director, 8, 42-51).

Полянский, В. (1999). Качество образования. М.: Наука (Polyansky, V. (1999). The quality of education. Moscow: Science).

Проєкт сприяння академічній доброчесності в Украні (SAIUP). Американські Ради. Режим доступу: http://www.saiup.org.ua/. (Academic Integrity Project in Ukraine (SAIUP). American Councils. Retrieved from: http:// www.saiup.org.ua/.

Пшенична, Л. (2019). Становлення академічної культури і доброчесності у вищій школі. Академічна культура дослідника в освітньому просторі: європейський та начіональний досвід: збірник матеріалів II Міжнародної науково-практичної конференції (м. Суми, 16-17 травня 2019 року). Суми: Видавництво СумДПУ імені А. C. Макаренка (Pshenychna, L. (2019). Formation of academic culture and integrity in higher school. Academic culture of the researcher in the educational space: European and national experience: collection of materials of the II International scientific-practical conference (Sumy, M ay 16-17, 2019). Sumy: Publishing House of Sumy State Pedagogical University named after A. S. Makarenko).

Семеног, О. (2016). Академічна культура - фундаментальний складник підготовки доктора філософії зі спеціальності 015 «Професійна освіта». Педагогічні науки: теорія, історія, інноваційні технології, 5, 192-203 (Semenog, 0. (2016). Academic culture - a fundamental component of the preparation of a doctor of philosophy in the specialty 015 "Professional Education". Pedagogical sciences: theory, history, innovative technologies, 5, 192-203).

Тализін, М. (2006). Проблеми якості освіти. К.: Наукова думка (Talizin, M. (2006). Problems of the quality of education. Kyiv: Scientific opinion).

Шишов, С. (2000). Школа: мониторинг качества образования. М.: Педагогическое общество России (Shyshov, S. (2000). School: monitoring of the quality of education. M oscow: Pedagogical Society of Russia).

Яременко, П. (2001). Якість освіти в України. К.: Лібра (Yaremenko, Р. (2001). The quality of education in Ukraine. Kyiv: Libra).

\section{PEЗЮME}

Ячменик Марина. Академическая добропорядочность как элемент обеспечения качества образования в высшей школе: опыт Сумского государственного педагогического университета имени А. С. Макаренко.

В научной работе предпринята попытка исследовать обеспечение принципов академической добропорядочности в образовательном пространстве высиих учебных заведений как основы качества образования.

На примере результатов опроса соискателей высшего образования и научнопедагогических сотрудников, проведенного в Сумском государственном педагогическом университете имени А.С. Макаренко по соблюдению принципов академической добропорядочности во время преподавания образовательнопрофрессиональных программ, предоставлено авторский комментарий относительно полученных ответов и предложен инструментарий внедрения принципов академической добропорядочности в высшей школе: проведение открытых лекций, тренингов, вебинаров, недель академической добропорядочности, разъяснение чели академической добросовестности и 
ответственности, причин и видов нарушений, способов борьбы с ними в научном и профессиональном взаимодействии стейкхолдеров.

Ключевые слова: академическая добропорядочность, качество образования, высшая школа, система обеспечения качества высшего образования, система обеспечения академической добропорядочности, учебная и научноисследовательская деятельность соискателей высшего образования.

\section{SUM MARY}

Yachmenyk Maryna Academic integrity as an element of ensuring the quality of education in higher school: experience of Sumy state pedagogical university named after A. S. Makarenko.

The article is devoted to the topical problem of dissemination principles of academic integrity as an element of ensuring the quality of education in higher school. The purpose of the article is to explore the system of academic integrity formation in the educational space of higher education institutions in native academic community as an element of ensuring the quality of education on the example of Sumy State Pedagogical University named after A. S. Makarenko. In the study the methods of generalization of scientific sources, analysis of educational literature, theoretical modeling, pedagogical experiment, etc. were used.

According to the modern requirements the basis of ensuring the quality of education in higher school is academic integrity - formation of a new academic culture on principles of academic freedom and social responsibility in conditions of a competitive university.

On the example of results of the poll for students and scientific and pedagogical workers in Sumy State Pedagogical University named after A. S. Makarenko about application principles of academic integrity during the teaching of the educationalprofessional program, we provide author's comment on the received answers and suggested means for implementing the principles of academic integrity in educational process on the example of Sumy State Pedagogical University named after A. S. Makarenko. For creating favorable conditions for the existence of academic integrity in the educational space we offer the complex of activities: through conducting open lectures, trainings, webinars, weeks of academic integrity, explanations for academic community about aims of academic honesty and responsibility, reasons and types of infraction, possible consequences and ways of struggle with them in interaction with subjects of scientific and professional community.

Practical experience of implementing principles of academic integrity helps to improve the system of ensuring the quality of education in the higher school.

Key words: academic integrity, quality of education, higher school, system of ensuring the quality of higher education, system of ensuring of academic integrity, educational and research activities of students. 